\title{
ASPEKTY BEZPIECZEŃSTWA PUBLICZNEGO W PLANOWANIU PRZESTRZENNYM
}

\begin{abstract}
Streszczenie. Zapewnienie bezpieczeństwa publicznego jest jednym z najważniejszych zadań spoczywających na państwie, co wynika m.in. z treści art. 5 Konstytucji Rzeczypospolitej Polskiej. Prawodawca w tekstach aktów normatywnych często posługuje się pojęciem bezpieczeństwa publicznego, jednak w żadnym z nich nie znajdziemy jego definicji legalnej. Zapewnieniem bezpieczeństwa publicznego zajmuje się wiele rodzajów podmiotów, od organów administracji rządowej, przez wyspecjalizowane jednostki, organy samorządu terytorialnego i organizacje samorządowe, aż po podmioty prywatne. Bezpieczeństwo publiczne jest również czynnikiem determinującym proces planowania przestrzennego, jego zapewnienie bowiem musi być uwzględnione przy planowaniu przyszłego zagospodarowania przestrzeni. Obowiązek ten wynika wprost z art. 1 ustawy o planowaniu i zagospodarowaniu przestrzennym.
\end{abstract}

Słowa kluczowe: bezpieczeństwo, bezpieczeństwo publiczne, planowanie przestrzenne, bezpieczeństwo w planowaniu przestrzeni, ustawa o planowaniu i zagospodarowaniu przestrzennym.

\section{ZAŁOŻENIA I CELE BADAWCZE}

Niniejsze opracowanie ma na celu przede wszystkim przedstawienie najistotniejszych kwestii związanych z zapewnieniem bezpieczeństwa publicznego w procesie planowania przestrzeni. Zaprezentowano jednak nie tylko aspekty bezpieczeństwa publicznego $\mathrm{w}$ tym procesie, ale również m.in. jego różnorakie definicje, organy odpowiedzialne za jego zapewnienie, czy też uwagi ogólne związane z planowaniem przestrzennym w Polsce. Do osiągnięcia zamierzonego celu wykorzystana została metoda analizy prawnej, przy pomocy której przestudiowano przepisy prawa powszechnie obowiązującego, orzecznictwo sądów administracyjnych oraz poglądy prezentowane w doktrynie. Zapewnienie bezpieczeństwa publicznego to niezwykle istotny aspekt działalności organów państwowych i samorządowych, a współcześnie często również podmiotów prywatnych. Planowanie przestrzenne natomiast to jedno z zadań stojących przed organami administracyjnymi, przede wszystkim organami gminy, czyli tej jednostki samorządu tery torialnego, która znajduje się najbliżej obywateli i najlepiej zna ich potrzeby. Podstawową tezą niniejszego opracowania jest zatem fakt, że prawidłowe

* Uniwersytet Wrocławski, Wydział Prawa, Administracji i Ekonomii, Zakład Nauki Administracji, karina.pilarz@uwr.edu.pl. 
zrealizowanie zadań związanych w planowaniem przestrzeni bezwzględnie wymaga wzięcia pod uwagę w procesie planistycznym aspektów związanych z bezpieczeństwem publicznym. Nie ma bowiem możliwości, aby w demokratycznym państwie prawa planowanie przestrzeni, a następnie materialna realizacja powziętych planów odbywały się z pominięciem konstytucyjnego obowiązku zapewnienia bezpieczeństwa. Mimo to w ustawie o planowaniu i zagospodarowaniu przestrzennym prawodawca nie posługuje się wprost pojęciem bezpieczeństwa publicznego. Używa natomiast takich terminów, jak „bezpieczeństwo ludzi i mienia” oraz „bezpieczeństwo państwa”, które wskazane zostały w artykule określającym zakres przedmiotowy ustawy wśród czynników, które muszą być uwzględnione $\mathrm{w}$ procesie planowania i zagospodarowania przestrzennego. Problem pojęciowy polega na tym, że w polskim porządku prawnym nie znajdziemy w ogóle definicji legalnej bezpieczeństwa publicznego (mimo że często jest używane przez ustawodawcę), zwykle natomiast wykorzystywane są różnego rodzaju zamienniki, takie jak bezpieczeństwo państwa, czy też bezpieczeństwo wewnętrzne. W opracowaniu przedstawione zostały rozmaite, zarówno prawne, jak i doktrynalne, ujęcia i próby zdefiniowania bezpieczeństwa publicznego wraz ze wskazaniem pewnych niekonsekwencji i różnic pojęciowych, co przyczyniło się do sformułowania tezy o konieczności wprowadzenia do polskiego porządku prawnego definicji legalnej analizowanego terminu.

\section{POJĘCIE BEZPIECZEŃSTWA PUBLICZNEGO}

W ujęciu ogólnym pojęcie bezpieczeństwa rozumiemy jako stan braku zagrożenia. Jego zapewnienie jest od czasów najdawniejszych jednym z najistotniejszych zadań, jakie stoją przed sprawującymi władzę. W polskim ustawodawstwie często możemy zetknąć się z pojęciem bezpieczeństwa, odnajdziemy je w ustawie zasadniczej, innych ustawach oraz w aktach niższego rzędu. Mimo to w żadnym $z$ aktów nie została zawarta jego legalna definicja. Wynikiem takiego stanu rzeczy są różne interpretacje spotykane w literaturze przedmiotu. Jak podkreśla Joanna Filaber, problemem jest również to, że w prawodawstwie stosowane są często pojęcia zbliżone, takie jak bezpieczeństwa państwa czy bezpieczeństwa wewnętrznego. Nie zostały natomiast określone kryteria, które pozwoliłyby na precyzyjne ich odróżnienie i określenie zasad ich stosowania. Zauważając ten problem, autorka wskazuje, że jego rozwiązaniem mogłoby być stworzenie przepisów ogólnego prawa administracyjnego, w których ustawodawca powinien zawrzeć pewne ważne definicje (w tym oczywiście definicję bezpieczeństwa publicznego), niezbędne do opracowania czytelnych i klarownych przepisów prawa (Filaber 2009, 259-261). W pełni zgadzam się z tym postulatem, nie ulega bowiem wątpliwości, że wprowadzenie definicji legalnej tak istotnego i często używanego przez ustawodawcę pojęcia przyczyniłoby się do wyeliminowania wszelkich 
terminologicznych niejasności i wieloznaczności oraz pozwoliło na jego tożsame rozumienie w kontekście przepisów różnego rodzaju ustaw i innych aktów normatywnych. Określenie bezpieczeństwa publicznego jest zatem potrzebne, bez względu na to, czy definicja ta miałaby znaleźć się w przepisach ogólnego prawa administracyjnego, czy też w ustawie szczegółowej, traktującej o kwestiach związanych $\mathrm{z}$ bezpieczeństwem.

Jedną z wartych przytoczenia doktrynalnych definicji odnoszących się do bezpieczeństwa jest definicja bezpieczeństwa państwa, sformułowana przez Waldemara Wołpiuka. Zgodnie z jej treścią jest to stan niezagrożenia, który daje państwu możliwość bezpiecznej egzystencji i rozwoju, a zapewnienie bezpieczeństwa dotyczy obrony zarówno przed istniejącymi, jak i przewidywanymi zagrożeniami (Wołpiuk 1998, 47). Andrzej Pakuła wskazuje natomiast na pewne obszary, które składają się na bezpieczeństwo publiczne. Zalicza do nich m.in. bezpieczeństwo prawne, energetyczne, finansowe, ekologiczne, gospodarcze, konsumenckie itp. Zaznaczając, że katalog ten nie jest kompletny, podkreśla wieloaspektowość i złożoność konstrukcji pojęciowej bezpieczeństwa publicznego (Pakuła 2009, 31).

Najważniejszym aktem w polskim porządku prawnym, który reguluje kwestie związane z bezpieczeństwem, jest Konstytucja Rzeczypospolitej Polskiej z dnia 2 kwietnia 1997 r. (Dz.U. z 1997 r. Nr 78, poz. 483 ze zm.). Pojęcie bezpieczeństwa wielokrotnie pojawia się w polskiej ustawie zasadniczej. Zapewnienie bezpieczeństwa obywateli, jako jednej z najważniejszych funkcji państwa, zostało wskazane już w art. 5 Konstytucji obok m.in. zapewnienia wolności i praw człowieka i obywatela. Bezpieczeństwo obywateli, podobnie jak integralność terytorialna, należy do kategorii „nienazwanych” zasad konstytucyjnych. Powodem tego jest fakt, że nie została sformułowana odrębna jednostka redakcyjna, z której wynikałaby te wartości (Bień-Kacała 2015, 16). Do tradycyjnego rozumienia bezpieczeństwa obywateli, a zatem pojmowania go jako działalność władz publicznych, która ma zapobiegać zagrożeniom zewnętrznym i wewnętrznym, należy dołączyć kwestie związane z bezpieczeństwem ekologicznym oraz energetycznym (Banaszak 2009, 52-53).

Bezpieczeństwo publiczne jest również jedną z przesłanek wymienionych w art. 31 ust. 3, dającą możliwość wprowadzenia ograniczeń w korzystaniu z konstytucyjnych wolności i praw. Konstytucja nadaje jednostkom pewne prawa i wolności, nie mogą one jednak mieć charakteru absolutnego. Wyznaczone zostały dwa wymogi, które muszą być spełnione, by ograniczenie mogło zostać wprowadzone. Wymóg formalny polega na tym, że ograniczenia te ustanawiane mogą być wyłącznie w drodze ustawy. Wymóg materialny wprowadzenia ograniczeń w korzystaniu z konstytucyjnych wolności i praw polega na tym, że mogą być one ustanowione dla ochrony jednej z sześciu wartości, wskazanych przez ustawodawcę konstytucyjnego (Garlicki 2017, 122-123). Jako pierwsza z przesłanek wymienione zostało właśnie bezpieczeństwo państwa. Pojęcie to odnosi się zarówno do bezpieczeństwa zewnętrznego, jak i wewnętrznego, a zatem warunkiem 
ograniczenia wolności i praw może być nie tylko zagrożenie zewnętrzne, ale również wewnętrzne, jeżeli jego zasięg jest na tyle istotny, że dotyka podstaw istnienia państwa, jego integralności lub też sytuacji ludności. Zapewnienie bezpieczeństwa państwa nie może ograniczać się wyłącznie do podjęcia działań, które mają na celu reakcję na zagrożenia, które już zaistniały, równie ważne jest podejmowanie działań, które mają zapobiegać ich występowaniu, dlatego niezbędne jest m.in. stworzenie skutecznego systemu obronnego. Należy również pamiętać, że bezpieczeństwo państwa oznacza stan braku zagrożeń dla istnienia państwa demokratycznego, a zatem wolność od możliwości zmiany istniejącego ustroju konstytucyjnego za pomocą przemocy (Garlicki, Zubik 2016, 84-85).

Zadania związane z zapewnieniem bezpieczeństwa publicznego, które jest jednym z podstawowych obowiązków państwa, realizowane są przez różnego rodzaju podmioty, skupione przede wszystkim w strukturach władzy wykonawczej. Ustawy samorządowe przekazują pewne uprawnienia w tym zakresie jednostkom samorządu terytorialnego, istotne funkcje spełniają również wyspecjalizowane formacje tworzone przez państwo, np. Policja, Straż Graniczna, Agencja Bezpieczeństwa Wewnętrznego, Państwowa Straż Pożarna. Istnieją także różnego rodzaju organizacje pozarządowe, które zajmują się działalnością związaną z bezpieczeństwem, jak ochotnicze straże pożarne (Olejniczak-Szałowska 2009, 533). W związku z prywatyzacją zadań publicznych w sferze bezpieczeństwa publicznego w sposób komercyjny działają podmioty prywatne, takie jak agencje ochrony osób i mienia. Ich celem jest uzyskanie większego standardu bezpieczeństwa niż ten, który zapewnia państwo (Pieprzny 2009, 566).

Zgodnie z art. 29 ustawy z dnia 4 września 1997 r. o działach administracji rządowej kwestie związane z ochroną bezpieczeństwa i porządku publicznego zaklasyfikowane są do spraw wewnętrznych (Dz.U. z 2018 r., poz. 762 ze zm.). W obecnie rządzącej Radzie Ministrów zadania te należą zatem do Ministra Spraw Wewnętrznych i Administracji. Rozszerzając jednak zakres bezpieczeństwa publicznego o wskazane wcześniej pojęcia pokrewne, takie jak bezpieczeństwa państwa, zauważyć możemy, że pewne zadania ze wskazanych dziedzin powierzone zostały również innym podmiotom, które nie wchodzą w skład działu zajmującego się sprawami wewnętrznymi (Filaber 2009, 250).

Zapewnienie porządku publicznego i bezpieczeństwa obywateli jest, zgodnie z ustawą z dnia 8 marca 1990 r. o samorządzie gminnym, jednym z zadań własnych gminy (Dz.U. z 2018 r., poz. 994 ze zm.; dalej: u.s.g.). Do kompetencji związanych $z$ bezpieczeństwem, określonych w u.s.g., należy opracowywanie przez wójta planu operacyjnego ochrony przed powodzią oraz ogłaszanie i odwoływanie przez niego pogotowia i alarmu przeciwpowodziowego. Wójt może również zarządzić ewakuację z obszarów zagrożonych, jeżeli niebezpieczeństwo nie może zostać usunięte w inny sposób. Bezpieczeństwo publiczne jest jedną z ustawowych przesłanek, uzasadniających wydawanie przez radę gminy przepisów porządkowych (art. 40 ust. 3 u.s.g.). 
Ustawa z dnia 5 czerwca 1998 r. o samorządzie powiatowym (Dz.U. z 2018 r., poz. 995 ze zm.; dalej: u.s.p). zawiera katalog zadań publicznych o charakterze ponadgminnym, które wykonywane są przez powiat. Jednym z nich są, zgodnie $\mathrm{z}$ art. 4 ustawy, kwestie związane z porządkiem publicznym i bezpieczeństwem obywateli. Organy administracji rządowej mogą również nałożyć na powiat obowiązek wykonania pewnych określonych czynności, związanych z usuwaniem zagrożeń dla bezpieczeństwa i porządku publicznego, a także z obronnością, w zakresie należącym do zadań powiatu. Przepis ten odnosi się do podejmowania odpowiednich działań w sytuacjach stanów nadzwyczajnych (Olejniczak-Szałowska 2009, 534). Do zadań rady powiatu, zgodnie z postanowieniami u.s.p., należy uchwalanie powiatowego programu zapobiegania przestępczości oraz ochrony bezpieczeństwa obywateli i porządku publicznego, a także dokonywanie oceny stanu bezpieczeństwa przeciwpożarowego i przeciwpowodziowego w powiecie. Bezpieczeństwo publiczne jest jedną z przesłanek wymienionych w art. 41 u.s.p., które uprawniają radę powiatu do wydawania przepisów porządkowych.

Bezpieczeństwo publiczne należy również do zadań o charakterze wojewódzkim, wykonywanych przez samorząd województwa, co wynika z ustawy z dnia 5 czerwca 1998 r. o samorządzie województwa (Dz.U. z 2018 r., poz. 913 ze zm.). Wojewoda, będący przedstawicielem Rady Ministrów w województwie, zapewnia natomiast współdziałanie organów administracji rządowej i samorządowej, kieruje ich działaniami w sferze zapobiegania zagrożeniom życia, zdrowia, mienia, a także zagrożeniom bezpieczeństwa państwa. Dokonuje również oceny stanu zabezpieczenia przeciwpowodziowego, opracowuje plan operacyjny ochrony przed powodzią, wykonuje i koordynuje zadania związane z obronnością, bezpieczeństwem państwa oraz zarządzaniem kryzysowym, a także może wydawać przepisy porządkowe dla zapewnienia bezpieczeństwa publicznego, co wynika z ustawy z dnia 23 stycznia 2009 r. o wojewodzie i administracji rządowej w województwie (Dz.U. z 2017 r., poz. 2234 ze zm.).

\section{ZARYS POLSKIEGO SYSTEMU PLANOWANIA PRZESTRZENNEGO}

Przedmiotem planowania przestrzennego jest oczywiście przestrzeń, którą rozumiemy jako przestrzeń geograficzną, społeczno-ekonomiczną, środowisko przyrodnicze, środowisko człowieka czy też terytorialny system społeczny (Parysek 2006, 29). Planowanie przestrzenne związane jest z opracowywaniem planów przestrzennych oraz procesem ich realizacji. Jest to praktyczna działalność, która zmierza to racjonalnego zagospodarowania terenów, uwzględniającego zarówno bieżące, jak i przyszłe potrzeby społeczeństwa. Jest to także interdyscyplinarna dziedzina naukowa, której przedmiotem są cele i sposoby racjonalnego gospodarowania przestrzenią (Korenik, Słodczyk 2005, 17). 
$\mathrm{W}$ obecnym porządku prawnym podstawową rolę $\mathrm{w}$ tym procesie odgrywa samorząd terytorialny. Wiąże się to z intensywnym rozwojem społeczno-gospodarczym po transformacji ustrojowej, industrializacją oraz decentralizacją funkcji państwa. W obrębie samorządu podstawowym podmiotem jest gmina, która jest również podstawowym podmiotem w systemie planowania przestrzennego. To organy gminy decydują o przeznaczeniu i zasadach zagospodarowania terenu, a ich rozstrzygnięcia są wiążące dla właścicieli gruntów, co określane jest mianem władztwa planistycznego gminy (Niewiadomski 2002, 81-83). Posiadany przez gminę atrybut władztwa planistycznego wiąże się również z samodzielnością planistyczną gminy, która wyznaczona jest jej publicznoprawnymi prawami i obowiązkami, mającymi swoje źródło wyłącznie w przepisach prawa. Władztwo gminy w dziedzinie planowania przestrzennego jest zatem normatywnie zdeterminowane (Jakimowicz 2012, 70-71).

Najważniejsze kwestie związane z procesem planistycznym zostały uregulowane w ustawie z dnia 27 marca 2003 r. o planowaniu i zagospodarowaniu przestrzennym (Dz.U. z 2017 r., poz. 1073 ze zm.; dalej: u.p.z.p.). Zgodnie z jej postanowieniami system planowania przestrzennego jest trójpoziomowy. Wyróżniamy poziom centralny, regionalny oraz lokalny, przy czym, jak już wspomniano wcześniej, najszerszy zakres kompetencji planistycznych posiada gmina. Ustawa nie daje natomiast istotnych uprawnień organom powiatu.

Podstawowym dokumentem planistycznym na szczeblu krajowym jest koncepcja przestrzennego zagospodarowania kraju (dalej: koncepcja), która nie jest prawnie wiążącym aktem. Sporządzana jest w koordynacji z planami zagospodarowania przestrzennego województwa. Na poziomie krajowym planowania przestrzennego prowadzona jest także współpraca transgraniczna i przygraniczna. Jak podkreśla Piotr Kwaśniak, współpraca ta często jest kwestią problematyczną. Przyczyną jest fakt, że systemy planistyczne poszczególnych państw nie są jeszcze w odpowiednim stopniu skoordynowane, mimo iż w ramach Unii Europejskiej następuje ujednolicanie prawodawstwa (Kwaśniak 2009, 94-95). Zgodnie z art. 47 u.p.z.p. koncepcja uwzględnia zasady zrównoważonego rozwoju kraju. Przygotowywana jest przez ministra właściwego do spraw rozwoju regionalnego we współpracy z ministrem właściwym do spraw budownictwa, planowania i zagospodarowania przestrzennego. Koncepcja określa uwarunkowania, cele, kierunki i działania niezbędne do osiągnięcia zrównoważonego rozwoju. Przyjmowana jest w drodze uchwały przez Radę Ministrów, a następnie przedstawiana do wiadomości Sejmowi RP przez Prezesa Rady Ministrów. Kwestiami planowania i zagospodarowania przestrzennego na szczeblu krajowym zajmują się więc zarówno minister właściwy ds. rozwoju regionalnego, jak i minister właściwy ds. budownictwa, planowania i zagospodarowania przestrzennego. Maciej Nowak postuluje połączenie tych działów administracji rządowej w jednym ministerstwie, co jest istotne dla kompleksowości polskiego systemu planowania przestrzennego (Nowak 2012, 161). 
Drugim szczeblem w tym systemie jest planowanie przestrzenne w województwie. Polega ono na podejmowaniu działań, które mają na celu kształtowanie i prowadzenie polityki przestrzennej o charakterze regionalnym. Organy województwa posiadają szeroki zakres działań w dziedzinie planowania i zagospodarowania przestrzennego (Bąkowski 2004, 149).

U.p.z.p. stanowi, że w województwie co najmniej raz na 20 lat sporządzany jest audyt krajobrazowy, którego zadaniem jest identyfikacja występujących na obszarze województwa krajobrazów przez określenie ich charakterystycznych cech i dokonanie oceny wartości. Projekt audytu sporządzany jest przez zarząd województwa. Audyt krajobrazowy zgodnie z art. 38b u.p.z.p. uchwalany jest przez sejmik województwa.

Dla obszaru w granicach administracyjnych województwa sejmik województwa uchwala plan zagospodarowania przestrzennego województwa, o czym stanowi art. 42 u.p.z.p. Plan ten, nie będąc aktem prawa miejscowego, nie jest źródłem prawa powszechnie obowiązującego w konstytucyjnym rozumieniu. Nie wywołuje zatem bezpośrednich skutków prawnych. Niektóre zawarte w nim zapisy mogą być wiążące wewnętrznie dla organów jednostek samorządu terytorialnego. Rolą planu jest koordynacja polityki przestrzennej na obszarze województwa, pełni on także funkcje koncepcyjne i informacyjne (Nowak 2012, 143-144). U.p.z.p. określa zakres przedmiotowy planu, który jest zróżnicowany pod względem merytorycznym. Jednak, ogólnie rzecz ujmując, dotyczy on czynników i uwarunkowań, które są najistotniejsze dla województwa z punktu widzenia zagospodarowania przestrzennego (Mickiewicz, Nowak 2012, 83-84).

Jak już wcześniej wspomniano, najszerszy zakres kompetencji planistycznych posiada gmina, do której zadań własnych należy kształtowanie i prowadzenie polityki przestrzennej na jej terenie. Obowiązek ten realizowany jest m.in. poprzez uchwalanie przez radę gminy dla obszaru w granicach administracyjnych gminy studium uwarunkowań i kierunków zagospodarowania przestrzennego gminy (dalej: studium), które określa politykę przestrzenną tej jednostki samorządu. Studium nie jest aktem prawa miejscowego, o czym wprost stanowi u.p.z.p. (art. 9 ust. 5). Jest ono natomiast aktem polityki administracyjnej, będącym wyrazem perspektywicznej polityki przestrzennej gminy. Poza określaniem polityki przestrzennej celem studium jest koordynacja ustaleń zawartych w miejscowych planach zagospodarowania przestrzennego, pełni ono również funkcję informacyjno-promocyjną (Szwajdler 2013, 37-38).

Celem miejscowego planu zagospodarowania przestrzennego (dalej: plan miejscowy) jest ustalenie przeznaczenia terenów, określenie sposobów ich zagospodarowania i zabudowy. Plan miejscowy podejmowany jest przez radę gminy $\mathrm{w}$ formie uchwały i jest to, zgodnie z art. 14 u.p.z.p., akt prawa miejscowego, zatem stanowi źródło powszechnie obowiązującego prawa w konstytucyjnym rozumieniu. Oznacza to, że jego ustalenia są wiążące zarówno dla organów władzy, jak i dla podmiotów spoza struktury władzy, czyli jednostek i ich organizacji. Ten 
normatywny charakter wynika m.in. z art. 6 u.p.z.p., zgodnie z którym ustalenia miejscowego planu zagospodarowania przestrzennego kształtują wraz z innymi przepisami sposób wykonywania prawa własności nieruchomości, i wiąże się z szeregiem wymagań, które dotyczą zasad tworzenia, ogłaszania oraz obowiązywania planu miejscowego (Bąkowski 2004, 86-87).

Zgodnie z art. 4 ust. 2, jeżeli dany obszar nie został objęty planem miejscowym, określenie sposobu zagospodarowania i warunków zabudowy terenu następuje w drodze decyzji o warunkach zabudowy i zagospodarowania terenu, tzn. decyzji o lokalizacji inwestycji celu publicznego lub decyzji o warunkach zabudowy, które wydaje co do zasady wójt (burmistrz, prezydent miasta).

\section{BEZPIECZEŃSTWO PUBLICZNE JAKO CZYNNIK DETERMINUJĄCY PROCES PLANOWANIA PRZESTRZENNEGO}

\subsection{Informacje podstawowe}

Planowanie jest niezwykle ważnym aspektem w całokształcie działalności gminy jako podstawowej jednostki samorządu terytorialnego, dotyczącej ochrony bezpieczeństwa publicznego. Do kompetencji organów gminy należy uchwalanie wielu planów i programów, które różnią się pod względem charakteru prawnego i pełnionej funkcji (Filaber 2016, 140-141). Jak już wcześniej wspomniano, zapewnienie bezpieczeństwa jest jednym z najistotniejszych i zarazem najstarszych zadań państwa. Nie ulega zatem wątpliwości, że realizacja tego zadania odbywać się musi również w ramach tak ważnej dziedziny aktywności państwa, jaką jest planowanie przestrzenne. Bezpieczeństwo publiczne jest jednym z czynników branych pod uwage przez organy planistyczne najpierw w procesie planowania, a następnie na etapie materialnej realizacji sformułowanych planów.

Jak sygnalizowano na początku niniejszego opracowania, w ustawie o planowaniu i zagospodarowaniu przestrzennym ustawodawca nie posługuje się wprost pojęciem bezpieczeństwa publicznego. Stosuje natomiast zamienniki: bezpieczeństwo ludzi i mienia oraz bezpieczeństwo państwa. Wymienia je w art. 1, w którym określił zakres przedmiotowy ustawy, w katalogu czynników uwzględnianych w planowaniu i zagospodarowaniu przestrzennym. Są to zatem pewne wartości, wytyczające kierunki procesu planowania i zagospodarowania przestrzennego. Czynniki, które zostały przez ustawodawcę wymienione w art. 1 ust. 2, traktować możemy jako zasady ogólne planowania i zagospodarowania przestrzennego. Wśród nich znajdują się zarówno takie, które posiadają ustawową definicję (zawartą w u.p.z.p. lub w innych przepisach materialnego prawa administracyjnego), jak i zasady stanowiące pojęcia niedookreślone (jak już wcześniej wspomniano, pojęcie bezpieczeństwa nie posiada definicji legalnej). Przepisy art. 1 u.p.z.p. nie mogą być traktowane jako bezpośrednio obowiązujące, wymagają dookreślenia w innych przepisach u.p.z.p. lub w innych ustawach prawa materialnego. Celem 
tych zasad, w tym oczywiście dotyczących bezpieczeństwa, jest wyznaczenie kierunków tworzenia prawa w postaci planów miejscowych oraz kierunków interpretacji przepisów prawa (Skrenty 2010, 246-247 i 258-259).

\subsection{Bezpieczeństwo ludzi i mienia}

W procesie planowania i zagospodarowania przestrzennego istotnym uwzględnianym czynnikiem jest wymienione wcześniej bezpieczeństwo ludzi i mienia, o którym mówi art. 1 ust. 2 pkt 5 u.p.z.p. Jeśli chodzi o mienie, na które, zgodnie z art. 44 ustawy z dnia 23 kwietnia 1964 r. - Kodeks cywilny (Dz.U. z 2018 r., poz. 1025 ze zm.), składa się własność i inne prawa majątkowe, dla potrzeb planowania przestrzeni liczą się przede wszystkim grunty i inne nieruchomości. W związku z tym wymagania ustawowe odnosić się będą głównie do prawa własności, ograniczonych praw rzeczowych na nieruchomościach, takich jak użytkowanie wieczyste, czy też praw obligacyjnych (dzierżawa, najem). Nie zostało to jednak wprost ograniczone przez ustawodawcę, należy zatem przyjąć, że również bezpieczeństwo innych praw majątkowych podlega ochronie w planowaniu przestrzennym. Materialnoprawnego powiązania, odnośnie do wymagań ochrony bezpieczeństwa mienia wskazanych w u.p.z.p., możemy się doszukiwać w przepisach ustaw szczególnych (Bąkowski 2004, 19-20). Można tutaj wymienić: ustawę z dnia 24 sierpnia 1991 r. o ochronie przeciwpożarowej (Dz.U. z 2018 r., poz. 620 ze zm.), ustawę z dnia 9 czerwca 2011 r. - Prawo geologiczne i górnicze (Dz.U. z 2017 r., poz. 2126 ze zm.) oraz ustawę z dnia 20 lipca 2017 r. - Prawo wodne (Dz.U. z 2017 r., poz. 1566 ze zm.).

Kwestie związane $\mathrm{z}$ bezpieczeństwem ludzi wiążą się natomiast ściśle z regulacjami prawa budowlanego. Przykładem jest konieczność uwzględnienia już na etapie planowania bezpiecznych dla ludzi, niepowodujących kolizji wjazdów i zjazdów oraz odległości od dróg publicznych, a także zapewnienie już na tym etapie odpowiedniej obsługi komunikacyjnej (Plucińska-Filipowicz i Wierzbowski 2018, 33). Sąd administracyjny podkreślił również, że ze względu na wymogi bezpieczeństwa ludzi przy projektowaniu i poszerzaniu dróg należy dążyć do tego, by przecinały się one pod kątem prostym (wyr. WSA w Warszawie z 25 stycznia 2012 r., IV SA/Wa 1524/11). Zagrożenia bezpieczeństwa ludności i jej mienia, poza art. 1, są również wymienione w art. 10 u.p.z.p., zawierającym katalog czynników, które muszą zostać uwzględnione w studium.

Istotną kwestią związaną z bezpieczeństwem, wymagającą uwzględnienia w planowaniu przestrzennym, jest zabezpieczenie przed powodzią. W tym celu należy ująć w studium oraz w planie miejscowym obszary szczególnego zagrożenia powodzią, na których obowiązywał będzie całkowity zakaz zabudowy lub też szczególne wymagania odnośnie do jej specyfiki. Jak wskazał sąd administracyjny, określenie w planie miejscowym tych obszarów, które zagrożone są niebezpieczeństwem powodzi, stanowi realizację ustawowego obowiązku, polegającego 
na kształtowaniu zagospodarowania terenów zagrożonych powodzią, aby zapewnić w procesie planowania przestrzennego bezpieczeństwo obywateli i ich mienia (wyr. WSA w Gdańsku z dnia 14 października 2015 r., II SA/Gd 25/15). Ważne jest, aby polityka przestrzenna na obszarach zalewowych godziła interesy wszystkich stron, a zatem zarówno poszczególnych mieszkańców, jak i gminy jako całości. Polityka ta musi być realizowana zgodnie z zasadami zrównoważonego rozwoju (Halama 2013, 318-321). Rolę planowania przestrzennego dla ochrony przeciwpowodziowej podkreśla m.in. Elżbieta Czekiel-Świtalska. Jej zdaniem podstawową formą ochrony jest pozostawienie terenów zalewowych jako wolnych od zabudowy, co przyczyni się do ograniczenia zarówno strat materialnych, jak i utraty życia przez ludzi i zwierzęta. Przyczyną zagrożeń jest według niej możliwość zabudowy terenów często się do tego nienadających, na podstawie decyzji o warunkach zabudowy, co prowadzi do chaosu przestrzennego. W celu zapewnienia skutecznej ochrony przeciwpowodziowej autorka postuluje konieczność wprowadzenia wymogu zgodności decyzji o warunkach zabudowy ze studium, podkreśla również konieczność zawierania w planach zabezpieczeń w postaci zbiorników retencyjnych i wałów przeciwpowodziowych (Czekiel-Świtalska 2011, 45-46).

Do kwestii bezpieczeństwa w planowaniu przestrzennym odnosi się tzw. Dyrektywa Seveso II, której celem jest zapobieganie poważnym awariom oraz ograniczenie ich skutków dla ludzi i środowiska. Sformułowane zostały wytyczne do dyrektywy, dotyczące oceny ryzyka wystąpienia poważnych awarii w zakładach przemysłowych, dokonywanej w planowaniu zagospodarowania przestrzennego. Zapisano w nich zasady, które mają przyczynić się do stosowania dobrych praktyk w planowaniu przestrzennym. Są to m.in.: istnienie metod oceny ryzyka/zagrożeń, zawarcie reprezentatywnego zbioru scenariuszy poważnych awarii w danych wyjściowych, podobieństwo decyzji planistycznych, istnienie kryteriów ustalania pożądanych limitów lub granic poziomu szkód, określenie zakresów obowiązków głównych uczestników oraz istnienie mechanizmów kontroli. Dodatkowo podkreślono rolę procesu planowania zagospodarowania przestrzeni w zapobieganiu i łagodzeniu zagrożeń związanych z poważnymi awariami, podkreślając jednocześnie, że jest to proces długotrwały. Planowanie przestrzenne jest szczególnie istotne w momencie wyboru lokalizacji dla nowego zakładu, który może stwarzać poważne zagrożenie (Biermann, Christou, Struck1 2006, 4, 7, 21).

Przykładem realizacji zasady bezpieczeństwa publicznego w planowaniu przestrzennym może być rola miejscowych planów urbanistycznych, zaznaczona przez Artura Jasińskiego, dla realizacji tzw. koncepcji niewidzialnego bezpieczeństwa. Polega ona na wkomponowaniu zabezpieczeń w miejski pejzaż. Koncepcja ta realizowana jest m.in. w ramach Planu Urbanistycznego Zabezpieczenia Stolicy, który wdrożony został w Waszyngtonie w 2002 roku. Zawiera on wytyczne, które mają przyczynić się do ograniczenia wizualnego oddziaływania zabezpieczeń i barier strefowych (Jasiński 2013, 227). 


\subsection{Bezpieczeństwo państwa}

Ważną rolę w planowaniu i zagospodarowaniu przestrzennym odgrywa inżynieria obronności i bezpieczeństwa państwa, które to wymogi prawodawca wymienił w art. 1 ust. 2 pkt 8 u.p.z.p. Związana jest ona z tworzeniem bezpiecznych rozwiązań środowiska antropogenicznego w przestrzeni życia człowieka. Obejmuje procesy związane z planowaniem przestrzeni, jej zagospodarowaniem oraz wieloletnią eksploatacją. Uwarunkowania obronności i bezpieczeństwa państwa wciąż ulegają zmianie, dlatego ważne jest dostosowywanie inżynierii bezpieczeństwa do aktualnych zagrożeń. Racjonalne planowanie przestrzeni jest niezwykle ważne dla gospodarki przestrzenno-obronnej kraju. Jednym z zadań obronnych niemających militarnego charakteru jest właśnie takie planowanie i zagospodarowanie przestrzeni, dzięki któremu powstają struktury przestrzenne charakteryzujące się trwałością, wygodą korzystania oraz odpornością na zagrożenia. Bezpieczeństwo jest zatem ściśle związane z przestrzenią, uwarunkowaniami środowiskowymi zarówno o charakterze przyrodniczym, jak i antropogenicznym oraz z jakością obiektów budowlanych, jakie tworzone są przez człowieka dla zaspokojenia jego życiowych potrzeb. W zakresie zapewnienia bezpieczeństwa państwa niezwykle istotne są kwestie związane z logistyką - lokalizowanie w przestrzeni dróg publicznych, linii kolejowych, wodnych szlaków komunikacyjnych oraz obiektów budowlanych służących obronności i bezpieczeństwu państwa (Baryłka 2016, 2-15). Do nieruchomości służących celom obronności i bezpieczeństwa państwa, poza ciągami komunikacyjnymi, zaliczamy również obiekty należące do wojska, Policji, Straży Granicznej, Państwowej Straży Pożarnej, budynki prokuratur, sądów czy Służby Więziennej (Skrenty 2010, 256). Ważnymi regulacjami prawnymi dotyczącymi budynków służących bezpieczeństwu są również przepisy wykonawcze, wydane na podstawie delegacji ustawowej zawartej w ustawie z dnia 7 lipca 1994 r. - Prawo budowlane (Dz.U. z 2018 r., poz. 1202), mającej charakter kompetencyjny. Jej celem jest zapewnienie odpowiedniego poziomu bezpieczeństwa oraz obronności państwa. Upoważnienie ma charakter fakultatywny (Gliniecki 2016, 145). Należy również zaznaczyć, że potrzeby obronności i bezpieczeństwa państwa objęte są szczególną ochroną prawną, co oznacza, że często zyskują pierwszeństwo nad innymi chronionymi przez prawo wartościami. Do takich sytuacji może również dojść w dziedzinie planowania i zagospodarowania przestrzennego, kiedy to przykładowo wymagania ochrony środowiska, prawo własności czy wolność gospodarcza muszą ustąpić potrzebom związanym z zapewnieniem bezpieczeństwa państwa, które staje się priorytetem (Bąkowski 2004, 22). Fakt istotności uwzględnienia kwestii związanych z bezpieczeństwem państwa przy określaniu form ochrony przyrody podkreślił w orzecznictwie Naczelny Sąd Administracyjny. Stwierdzono, że ustalanie zasad zagospodarowania terenu w obszarze chronionego krajobrazu musi brać pod uwagę, czy znajdują się na nim miejsca przeznaczone na potrzeby związane z obronnością i bezpieczeństwem państwa (wyr. NSA oz. w Poznaniu z dnia 17 grudnia 1996 r., II SA/Po 898/96). 
Zgodnie z przepisami art. 11 pkt 6 lit. d) u.p.z.p. po podjęciu przez radę gminy uchwały o przystąpieniu do sporządzenia studium organ wykonawczy gminy występuje m.in. do właściwych organów bezpieczeństwa państwa o opinie dotyczące rozwiązań przyjętych $\mathrm{w}$ projekcie. $\mathrm{Z}$ organami bezpieczeństwa państwa uzgadniany jest również projekt planu miejscowego - art. 17 pkt 6 lit. b) tiret czwarte; uzgodnień dokonuje wójt, burmistrz lub prezydent miasta po podjęciu przez radę gminy uchwały o przystąpieniu do sporządzenia planu miejscowego. Fakt konieczności uzgadniania z organami wojskowymi planów miejscowych w takich sprawach, jak granice terenów zamkniętych czy ich strefy ochronne, został podkreślony w orzecznictwie administracyjnym (wyr. WSA w Białymstoku z dnia 29 maja 2013 r., Sa/Bd 313/13). Kolejną istotną kwestią podkreśloną w orzecznictwie administracyjnym jest fakt, że ani u.p.z.p., ani żaden przepis szczególny nie nakładają obowiązku dokonania uzgodnień w organami, których zadaniem jest ochrona bezpieczeństwa i porządku publicznego, w przypadku postępowania o ustalenie warunków zabudowy i zagospodarowania terenu (wyr. WSA w Olsztynie z 13 grudnia 2007 r., II SA/O1 857/07).

Do roku 2014 obowiązywało rozporządzenie Ministra Infrastruktury, które określało sposób uwzględniania w zagospodarowaniu przestrzennym potrzeb obronności i bezpieczeństwa państwa (Dz.U. z 2004 r. Nr 125, poz. 1309). Zgodnie $\mathrm{z}$ tym rozporządzeniem uwzględnianie potrzeb bezpieczeństwa państwa w procesie zagospodarowania przestrzeni ma na celu przygotowanie oraz przeciwdziałanie zagrożeniom wewnętrznym poprzez zapewnienie odpowiednich warunków m.in. do ochrony bezpieczeństwa i porządku publicznego. W 2015 Minister Obrony Narodowej wydał decyzję, dotyczącą sposobu realizacji w resorcie obrony narodowej zadań z zakresu planowania przestrzennego (Dz.Urz. MON z 2015 r., poz. 277). W decyzji tej określone zostały zadania poszczególnych osób, które zajmują kierownicze stanowiska w Ministerstwie Obrony Narodowej, w takich sprawach, jak kształtowanie zagospodarowania przestrzennego kraju i terenów zamkniętych, ustalanie lokalizacji inwestycji służących obronności państwa oraz ustalanie stref ochronnych terenów zamkniętych.

\section{PODSUMOWANIE}

Zapewnienie bezpieczeństwa, będące jedną z najważniejszych funkcji państwa, odgrywa ważną rolę w wielu dziedzinach jego aktywności, w tym również $\mathrm{w}$ procesie planowania przestrzennego. $\mathrm{W}$ celu zagwarantowania publicznego bezpieczeństwa organy planistyczne muszą uwzględniać w uchwalanych przez siebie planach takie czynniki, jak potrzeby obronności państwa, ochronę przeciwpowodziową, czy też zabezpieczenie przed stwarzającymi zagrożenie zakładami przemysłowymi. 


\section{BIBLIOGRAFIA}

Banaszak, Bogusław. 2009. Konstytucja Rzeczypospolitej Polskiej. Komentarz. Warszawa: Wydawnictwo C.H. Beck.

Baryłka, Adam. 2016. „Wprowadzenie do zagadnień obronności i bezpieczeństwa państwa w planowaniu i zagospodarowaniu przestrzennym". Safety \& Defence 1: 1-19.

Bąkowski, Tomasz. 2004. Ustawa o planowaniu i zagospodarowaniu przestrzennym. Komentarz. Kraków: Zakamycze.

Bień-Kacała, Agnieszka. 2015. „Bezpieczeństwo w Konstytucji RP z 1997 r. - wstępna diagnoza”. Przeglad Prawa Konstytucyjnego 2 (24): 11-28.

Biermann, Tobias, Michalis Christou, Michael Struckl. 2006. Wytyczne w zakresie planowania zagospodarowania przestrzennego w kontekście artykulu 12 Dyrektywy Seveso II 96/82/WE zmienionej dyrektywa 105/2003/WE. [b.m.]: Wspólnotowe Centrum Badawcze.

Czekiel-Świtalska, Elżbieta. 2011. „Planowanie przestrzenne a zagrożenia”. Czasopismo Techniczne. Architektura 17: 43-47.

Filaber, Joanna. 2009. „Pojęcie bezpieczeństwa publicznego w prawie administracyjnym (wybrane uwagi)". W Wrocławskie Studia Erazmiańskie. Zeszyty Studenckie - Studia Erasmiana Wratislaviensia. Acta Studentium. Prace prawnicze, administratywistyczne i historyczne. Red. Mirosław Sadowski, Piotr Szymaniec. 244-262. Wrocław: Katedra Doktryn Politycznych i Prawnych WPAiE Uniwersytetu Wrocławskiego, Koło Naukowe Doktryn Politycznych i Prawnych WPAiE.

Filaber, Joanna. 2016. Ochrona bezpieczeństwa publicznego w gminie. Warszawa: Difin.

Garlicki, Leszek. 2017. Polskie prawo konstytucyjne. Zarys wykładu. Warszawa: Wolters Kluwer.

Garlicki, Leszek, Marek Zubik. 2016. Konstytucja Rzeczypospolitej Polskiej. Komentarz. Warszawa: Wydawnictwo Sejmowe.

Gliniecki, Andrzej. 2016. Prawo budowlane. Komentarz. Warszawa: Wolters Kluwer.

Halama, Arkadiusz. 2013. „Polityka przestrzenna na terenach zalewowych w małych miastach”. Studia Ekonomiczne 144: 311-322.

Jakimowicz, Wojciech. 2012. „O normatywnych podstawach władztwa planistycznego gminy”. W Kierunki reformy prawa planowania i zagospodarowania przestrzennego. Red. Igor Zachariasz. 70-88. Warszawa: Wolters Kluwer.

Jasiński, Artur. 2013. Architektura w czasach terroryzmu. Miasto - przestrzeń publiczna-budynek. Warszawa: Wolters Kluwer.

Korenik, Stanisław, Janusz Słodczyk. 2005. Podstawy gospodarki przestrzennej-wybrane aspekty. Wrocław: Wydawnictwo Akademii Ekonomicznej we Wrocławiu.

Kwaśniak, Piotr. 2009. Plan miejscowy w systemie zagospodarowania przestrzennego. Warszawa: LexisNexis.

Mickiewicz, Paweł, Maciej Nowak. 2012. Plan zagospodarowania przestrzennego województwa jako instrument zarządzania rozwojem regionalnym. Warszawa: CeDeWu.pl Wydawnictwa Fachowe.

Niewiadomski, Zygmunt. 2002. Planowanie przestrzenne. Zarys systemu. Warszawa: LexisNexis.

Nowak, Maciej. 2012. Ustawa o planowaniu i zagospodarowaniu przestrzennym. Komentarz. Warszawa: Wydawnictwo C.H. Beck.

Olejniczak-Szałowska, Ewa. 2009. „Ochrona bezpieczeństwa i porządku publicznego jako zadanie powiatu. Zarys problemu". W Między tradycją a przyszłościa w nauce prawa administracyjnego. Ksiega jubileuszowa dedykowana Profesorowi Janowi Bociowi. Red. Jerzy Supernat. 532-544. Wrocław: Wydawnictwo Uniwersytetu Wrocławskiego. 
Pakuła, Andrzej. 2009. „Bezpieczeństwo publiczne jako dobro wspólne (kilka uwag i refleksji)”. W Bezpieczeństwo wewnętrzne $w$ działaniach terenowej administracji publicznej. Red. Andrzej Chajbowicz, Tadeusz Kocowski. 29-35. Wrocław: Kolonia Limited.

Parysek, Jerzy. 2006. Wprowadzenie do gospodarki przestrzennej. Poznań: Wydawnictwo UAM.

Pieprzny, Stanisław. 2009. „Podmioty prywatne w ochronie bezpieczeństwa i porządku publicznego". W Między tradycja a przyszłościa w nauce prawa administracyjnego. Księga jubileuszowa dedykowana Profesorowi Janowi Bociowi. Red. Jerzy Supernat. 554-566. Wrocław: Wydawnictwo Uniwersytetu Wrocławskiego.

Plucińska-Filipowicz, Alicja, Marek Wierzbowski. 2018. Ustawa o planowaniu i zagospodarowaniu przestrzennym. Komentarz. Warszawa: Wolters Kluwer.

Skrenty, Żaklina. 2010. „Podstawowe zasady planowania przestrzennego - istota i cele ustanowienia”. Studia Lubuskie 7: 245-260.

Supernat, Jerzy (red.). 2009. Między tradycja a przyszłościa w nauce prawa administracyjnego. Ksiega jubileuszowa dedykowana Profesorowi Janowi Bociowi. Wrocław: Wydawnictwo Uniwersytetu Wrocławskiego.

Szwajdler, Wojciech. 2013. Aspekty planowania i zagospodarowania przestrzennego. Warszawa: Wolters Kluwer.

Wołpiuk, Waldemar. 1998. Siły Zbrojne w regulacjach Konstytucji RP. Warszawa: Wydawnictwo Naukowe Scholar.

Akty prawne

Decyzja Nr 386/MON z dnia 29 września 2015 r. w sprawie realizacji w resorcie obrony narodowej zadań z zakresu planowania i zagospodarowania przestrzennego (Dz.Urz. MON z 2015 r., poz. 277).

Konstytucja Rzeczypospolitej Polskiej z dnia 2 kwietnia1997 r. (Dz.U. z 1997 r. Nr 78, poz. 483 ze zm.).

Rozporządzenie Ministra Infrastruktury z dnia 7 maja 2004 r. w sprawie sposobu uwzględniania $\mathrm{w}$ zagospodarowaniu przestrzennym potrzeb obronności i bezpieczeństwa państwa (Dz.U. z 2004 r. Nr 125, poz. 1309).

Ustawa z dnia 23 kwietnia 1964 r. - Kodeks cywilny (Dz.U. z 2018 r., poz. 1025 ze zm.).

Ustawa z dnia 8 marca 1990 r. o samorządzie gminnym (Dz.U. z 2018 r., poz. 994 ze zm.).

Ustawa z dnia 24 sierpnia 1991 r. o ochronie przeciwpożarowej (Dz.U. z 2018 r., poz. 620 ze zm.).

Ustawa z dnia 7 lipca 1994 r. - Prawo budowlane (Dz.U. z 2018 r., poz. 1202).

Ustawa z dnia 4 września 1997 r. o działach administracji rządowej (Dz.U. z 2018 r., poz. 762 ze zm.).

Ustawa z dnia 5 czerwca 1998 r. o samorządzie powiatowym (Dz.U. z 2018 r., poz. 995 ze zm.).

Ustawa z dnia 5 czerwca 1998 r. o samorządzie województwa (Dz.U. z 2018 r., poz. 913 ze zm.).

Ustawa z dnia 27 marca 2003 r. o planowaniu i zagospodarowaniu przestrzennym (Dz.U. z 2017 r., poz. $1073 \mathrm{ze} \mathrm{zm}$.).

Ustawa z dnia 23 stycznia 2009 r. o wojewodzie i administracji rządowej w województwie (Dz.U. z 2017 r., poz. 2234 ze zm.).

Ustawa z dnia 9 czerwca 2011 r. - Prawo geologiczne i górnicze (Dz.U. z 2017 r., poz. 2126 ze zm.).

Ustawa z dnia 20 lipca 2017 r. - Prawo wodne (Dz.U. z 2017 r., poz. 1566 ze zm.).

\section{Orzecznictwo}

Wyrok Naczelnego Sądu Administracyjnego oz. w Poznaniu z dnia 17 grudnia 1996 r., sygn. akt II SA/Po 898/96.

Wyrok Wojewódzkiego Sądu Administracyjnego w Białymstoku z dnia 29 maja 2013 r., sygn. akt II Sa/Bd 313/13. 
Wyrok Wojewódzkiego Sądu Administracyjnego w Gdańsku z dnia 14 października 2015 r., sygn. akt II SA/Gd 25/15.

Wyrok Wojewódzkiego Sądu Administracyjnego w Olsztynie z dnia 13 grudnia 2007 r., sygn. akt II SA/Ol 857/07.

Wyrok Wojewódzkiego Sądu Administracyjnego w Warszawie z dnia 25 stycznia 2012 r., sygn. akt IV SA/Wa 1524/11.

\title{
Karina Pilarz
}

\section{ASPECTS OF PUBLIC SAFETY IN LAND DEVELOPMENT PLANNING PROCESS}

\begin{abstract}
Provision of public safety is one of the most important public tasks of public administration. The obligation to perform the aforementioned task by the public administration results from article 5 of the Constitution of the Republic of Poland which states that "The Republic of Poland shall safeguard the independence and integrity of its territory and provide freedoms and rights of persons and citizens, the security of the citizens, safeguard the national heritage and shall provide the protection of the natural environment pursuant to the principles of sustainable development." Even though the legislator very often uses the term "public safety" in the universally binding acts of law, one cannot find any legal definition of this term. It is worth mentioning here that in Poland many types of entities are responsible for providing public safety. Among these entities, one can find organs of governmental administration, specialized units, organs of territorial self-government units and private entities. Because public safety is an important factor in a land development planning process, it must be taken into account in planning future development of the space. This obligation results from article 1 of the Polish Spatial Planning and Land Development Act.
\end{abstract}

Keywords: safety, public safety, development planning process, spatial planning and land development act. 